\title{
L'impaginato come forma narrativa. Le riviste sperimentali di architettura negli anni Sessanta
}

Manuela Piscitelli

\section{Abstract}

L'articolo propone una lettura delle pubblicazioni indipendenti degli anni Sessanta e primi anni Settanta con particolare riferimento a quelle di architettura, analizzandone le caratteristiche visive. In quel periodo infatti si realizzarono innovative ricerche e sperimentazioni di narrativa grafica, in cui la composizione della pagina assunse una fondamentale importanza nella comunicazione dei contenuti. La sovrapposizione di elementi visivi con la tecnica del collage, l'integrazione di testi e immagini, l'uso dei caratteri, divennero funzionali all'intento comunicativo, stabilendo una stretta relazione tra la teoria architettonica e la sua rappresentazione e comunicazione ad un pubblico di nicchia interessato al dibattito sul rinnovamento del linguaggio architettonico.

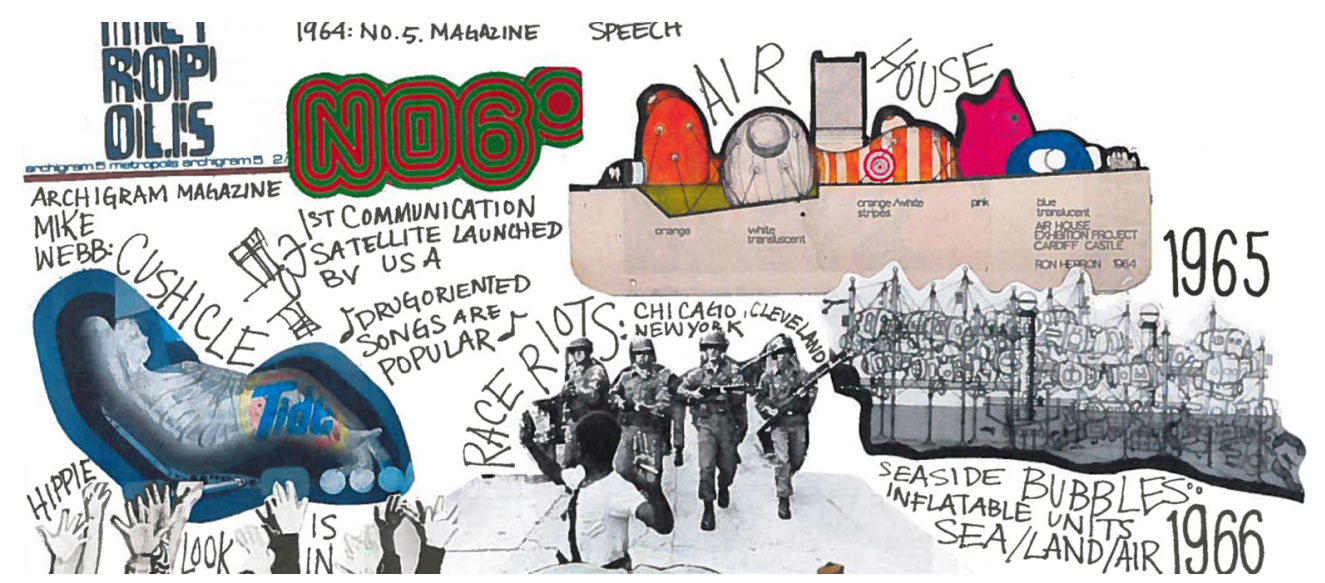


La pagina stampata intesa come dispositivo visivo ha una funzione narrativa che, in modo particolarmente evidente nell'ambito della pagina illustrata, definisce un codice di comunicazione. I suoi tempi, al contrario della narrazione cinematografica in cui sono prestabiliti nel momento del montaggio, dipendono dall'utente, ma vengono guidati dal grafico che suggerisce percorsi visivi, pause, spazi in cui la narrazione si svolge. Questo tipo di ricerca grafica è stata portata avanti a partire dagli anni Venti del Novecento, quando le sperimentazioni delle avanguardie artistiche, la grafica art nouveau che unificava figura e immagini dalle forme sinuose e ricche di elementi decorativi [Grazioli 200 I], la rottura della gabbia tipografica operata dai futuristi con le parole in libertà [Hulten 1986], le innovazioni del Bauhaus sui caratteri tipografici e l'orientamento dei testi nella composizione della pagina [Wingler 1987], furono tutti elementi che confluirono nella composizione tipografica di volumi e riviste illustrate.

Le prime riviste ad avviare queste sperimentazioni, dove la sequenza e l'ordine visivo in cui i contenuti venivano presentati si ponevano essi stessi come una forma narrativa, furono quelle del settore della moda, che già nel primo dopoguerra si avvalsero della collaborazione di artisti, illustratori e poi fotografi, creando pagine in cui le immagini si susseguivano dando vita a vere e proprie narrazioni, definendo scenari ed ambientazioni che potessero suscitare il desiderio dell'acquisto di un capo per entrare a far parte dell'immaginario proposto.

Fig. I. Bruno Munari, Libro Illeggibile $M n$ I. 1949.
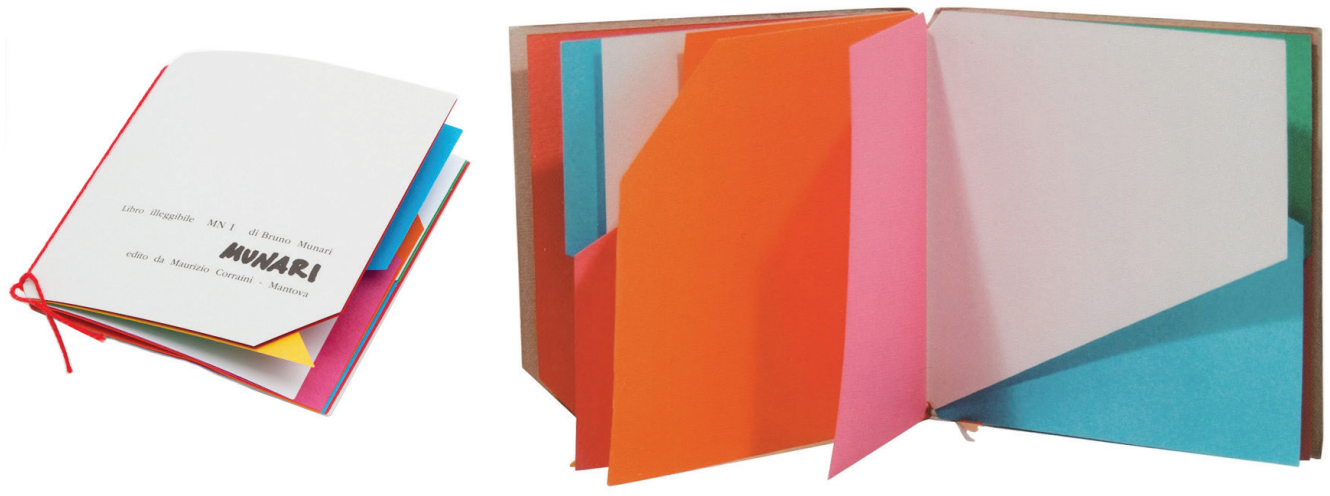

Nel secondo dopoguerra, su un fronte ancora più spinto nell'ambito della narrativa grafica, si collocano sperimentazioni quali i 'libri illeggibili' realizzati da Bruno Munari a partire dal 1949. Utilizzando carte di tipo e grana diversa, tagliate, forate o strappate in vari modi ed infine rilegate a formare un libro, Munari concepisce una narrazione che non utilizza parole ma segue un filo puramente visivo. Rinunciando ad essere supporto per il testo, è la carta che comunica un messaggio attraverso il formato, il colore, i tagli e la loro alternanza, una narrazione da seguire utilizzando i sensi [Munari 1993]. Al contrario del libro oggetto, che puntava sull'aspetto fisico del pezzo unico esponibile come un'opera d'arte, il libro illeggibile è interessante dal punto di vista della rappresentazione in quanto punta sulle potenzialità narrative. "La pagina, come unità spaziale, acquista in rapporto alle altre pagine una dimensione temporale, diventando un elemento ritmico. Non si impone un percorso obbligato, il libro muta col mutare del lettore, dimostrando che è superfluo arrivare alle pagine sciolte delle avanguardie. Si giunge così a un apparente paradosso: girare le pagine è un'esperienza narrativa ma non letteraria" [Falcinelli 2014, p. 24I].

Negli anni Sessanta le riviste illustrate si pongono come supporto per le sperimentazioni più innovative dal punto di vista della composizione tipografica, sfruttando tutte le potenzialità narrative della pagina stampata in diversi settori tra cui quello dell'architettura, ed in particolare attraverso pubblicazioni di nicchia spesso autoprodotte nelle stesse scuole di architettura. La rivista in quanto dispositivo visivo è dotata di una propria identità, fatta di uno stile grafico, un formato, un'architettura della pagina, un utilizzo dei caratteri tipografici e della 
gabbia che la rendono unica e riconoscibile da parte dei lettori. Questo è un primo livello di comunicazione, che si potrebbe definire intrinseco, ed è profondamente legato al pubblico a cui la rivista si rivolge, alle innovazioni tecniche in campo tipografico, alle tendenze dell'epoca in campo artistico e grafico. II secondo livello di comunicazione è quello dei contenuti che la rivista seleziona e sceglie di veicolare. La maggior parte degli studi pubblicati riguardo alle riviste affrontano il secondo livello di comunicazione, relativo ai contenuti, mentre la comunicazione intrinseca, la messa in scena per così dire dei contenuti, generalmente non presa in considerazione, può essere uno spunto di riflessione di grande interesse per il settore della rappresentazione. Anche nel campo dell'architettura, le riviste indipendenti note sotto la definizione di 'piccole riviste' per il ruolo non commerciale e la produzione in poche copie con una circolazione limitata, sono state oggetto di studio riguardo all'innovatività dei contenuti veicolati piuttosto che riguardo al modo, altrettanto innovativo, in cui graficamente questi contenuti sono stati messi in scena attraverso modalità di narrativa grafica completamente differenti dalle classiche rappresentazioni dei progetti nella pubblicistica di settore. La definizione di piccole riviste non è applicata strettamente alle riviste, ma a tutta l'attività pubblicistica indipendente che ha alimentato il dibattito sul rinnovamento dell'architettura in quel periodo, fornendo indicazioni sulle nuove tendenze [Scott Brown 1968].

Una delle figure più significative che ha operato nell'ambito della grafica editoriale dell'epoca è certamente Quentin Fiore. La sua presenza in copertina accanto all'autore, a pari importanza, in pubblicazioni rivoluzionarie come The medium is the massage (1967) con Marshall McLuhan e I seem to be a verb di Richard Bukminister Fuller (1970) mostrano come la modalità grafica di presentazione avesse pari rilevanza nella trasmissione rispetto ai
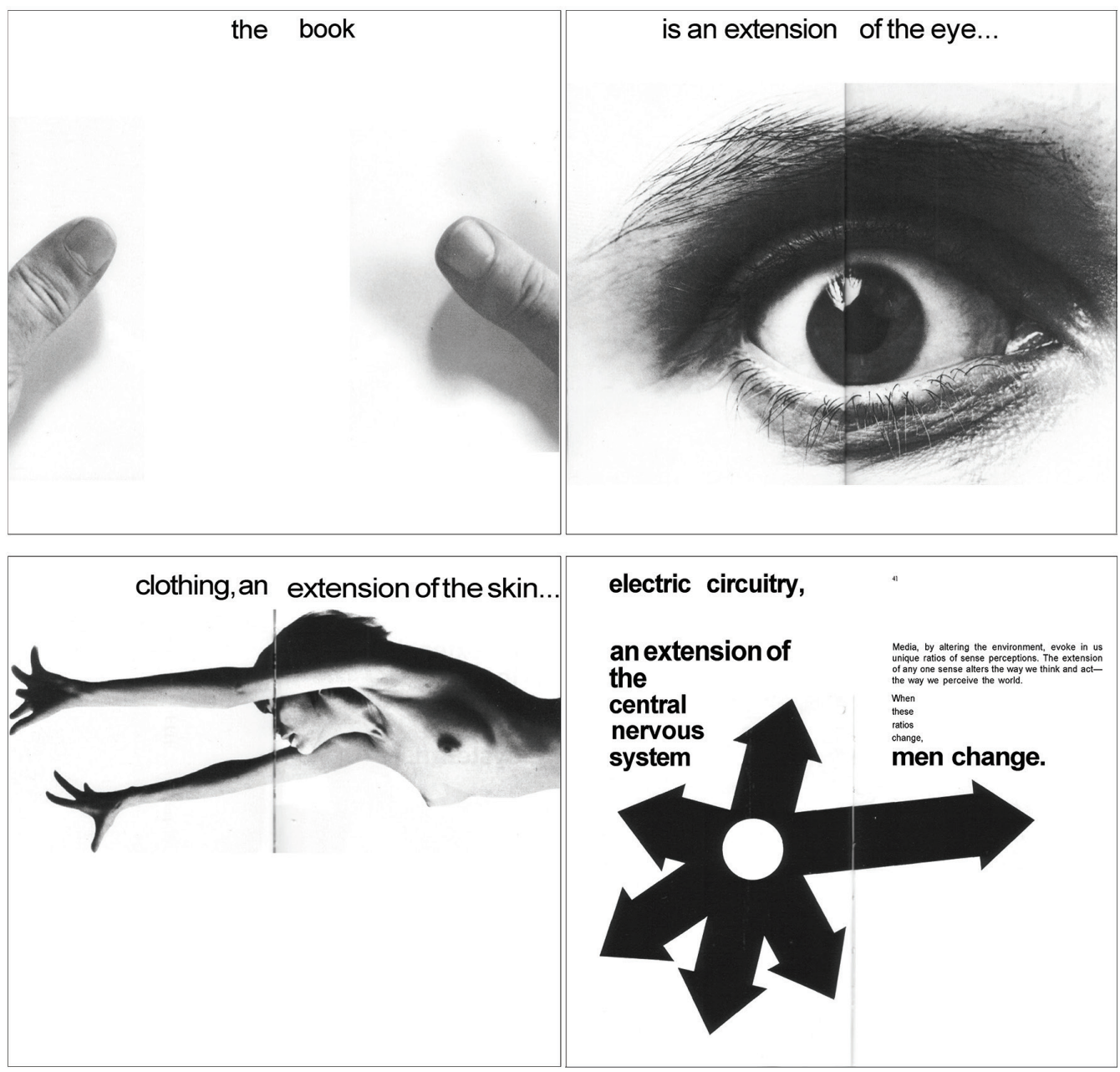
contenuti da veicolare. Testi e codici visivi si fondono in una sintesi in cui la comunicazione, oltre che alla componente verbale, è affidata a quella visiva costituita dalla composizione di testi e immagini sulla doppia pagina, la deformazione onomatopeica dei caratteri, i diversi pesi visivi, disposizione e orientamento dei testi, l'alternanza di pagine con lo sfondo bianco e pagine con lo sfondo nero.

II testo di Fuller I seem to be a verb, che tratta della società del futuro e del design sostenibile, presenta un collage di immagini di oggetti della società globalizzata, giustapposti provocatoriamente attraverso un montaggio visivo fatto di continui rimandi che forniscono il senso della narrazione. La composizione è realizzata sulla doppia pagina divisa in fasce orizzontali, di cui la superiore è in bianco e nero, l'inferiore in verde e capovolta, per cui due diverse narrazioni condividono lo stesso spazio visivo ed il volume può essere letto dritto o capovolto con contenuti e significati diversi.

Tra gli anni Sessanta e Settanta le riviste indipendenti di architettura costituirono un campo aperto al dibattito, laboratori di idee e sperimentazioni espressi con linguaggi nuovi e avanguardistici. Come strumento per la diffusione di nuove idee, si riallacciano alle riviste degli anni Venti, dalle cui pagine i maestri dell'architettura avevano divulgato le proprie idee, come L'Esprit Nouveau di le Corbusier (1920-1925) e G: Material zur elementaren Gestaltung di Mies van der Rohe (1923-1926), dalle quali riprendono il ruolo di canale di dibattito per le avanguardie. Mentre L'Esprit Nouveau aveva un'impostazione tipografica tradizionale, in G la ricerca grafica era parte del progetto comunicativo, come dimostra l'impaginato tipografico costruttivista realizzato da El Lissitzky [Mertins 20 I0].

Dal punto di vista del linguaggio grafico, negli anni Sessanta molte riviste furono composte dagli stessi curatori, attraverso la sovrapposizione di diversi elementi visivi con la tecnica del collage: frammenti di immagini, fotografie, disegni, testi scritti a mano o stampati in combinazioni di diversi tipi di caratteri, il tutto composto sulla pagina in combinazioni dinamiche

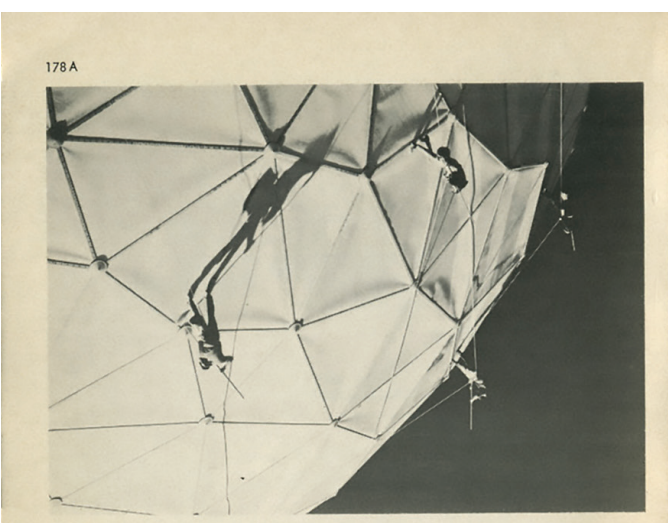

E OF UNBIASED INTEGR WI ISOW $\exists G \quad$ NVW VNIHO

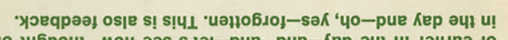

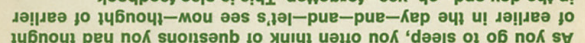

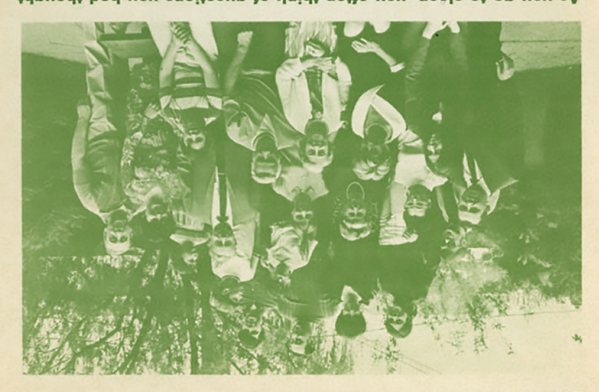

8841

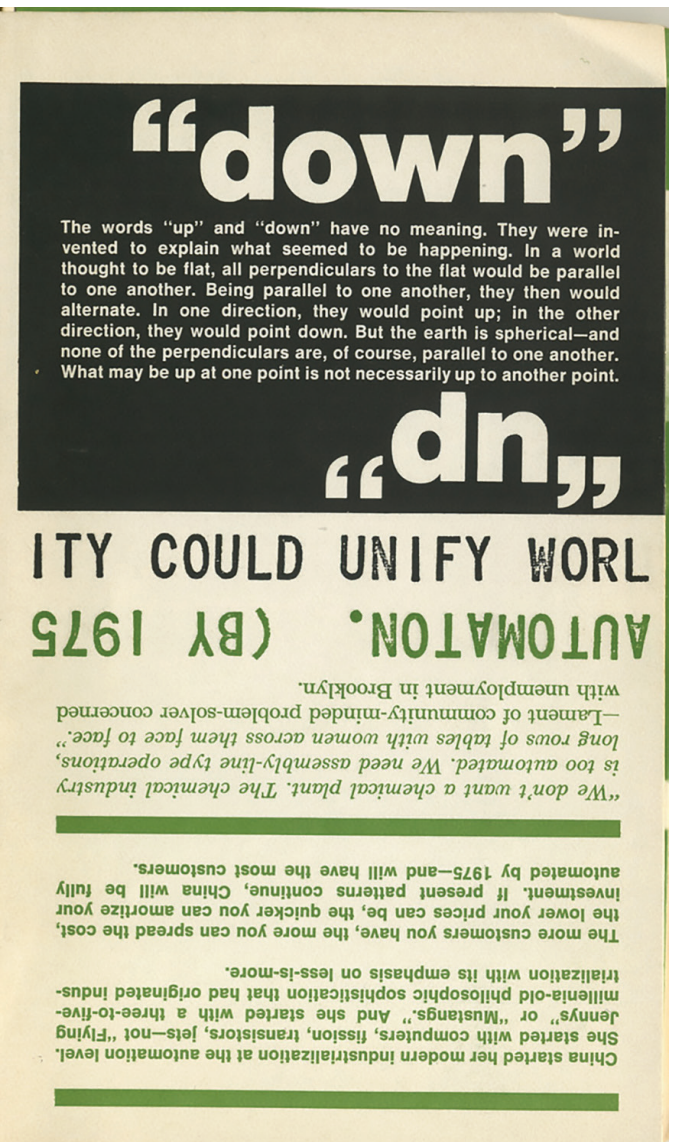


che guidavano la percezione in una narrazione significativa. Anche il supporto di queste composizioni poteva essere variabile, carte e cartoncini di varia grammatura e colore, fogli semplici rilegati in vario modo o sciolti, grandi formati ripiegati [Peck 1985]. La modalità in cui i contenuti venivano presentati era funzionale all'intento comunicativo, in una stretta relazione tra la teoria architettonica (i progetti più interessanti e innovativi erano spesso destinati a restare sulla carta) e la sua rappresentazione e comunicazione ad un pubblico di nicchia interessato al dibattito. Pubblicazioni di questa tipologia si trovano in diverse aree geografiche, accomunate da mezzi espressivi derivati dal linguaggio grafico delle avanguardie artistiche, dalla volontà di staccarsi dalle convenzioni del passato, dalla sperimentazione di nuove modalità espressive che potessero veicolare nuovi contenuti, discostandosi profondamente dalle tradizionali riviste di architettura, caratterizzate dalla presentazione di elaborati tecnici illustrativi dei progetti e testi didascalici. Queste pubblicazioni sono state anche portavoce di quella che Germano Celant ha definito architettura radicale italiana [Celant 1972]. I codici visivi del periodo vennero influenzati fortemente dai programmi spaziali, che spinsero ad una riflessione sull'architettura e sull'ambiente in spazi da colonizzare o ambienti inabitabili. Queste riflessioni sono evidenti in riviste come Clip-Kit, Archigram, e Bau, oltre che nei lavori pubblicati dal gruppo Superstudio sulle pagine della rivista Casabella. A proposito di riviste strutturate come Casabella o Architectural Design è stato notato come in questo stesso periodo ebbero un temporaneo distacco dalle logiche più commerciali che le caratterizzavano, per farsi portavoce dei gruppi e dei dibattiti del momento. Le nuove logiche editoriali sono visibili anche nel layout delle pagine e nella grafica della copertina, che si discostarono dall'impostazione tradizionale per diventare uno spazio di sperimentazione appropriato ai contenuti che in quel momento stavano veicolando. Casabella tra il 1970 e il 1975, sotto la direzione di Alessandro Mendini, diede ampio spazio alle ricerche dell'architettura radicale e allo stesso tempo rinnovò la grafica. Le copertine di quegli anni sono provocatorie, non riportano progetti come tipicamente avveniva fino a quel momento e continuerà in seguito, utilizzano collage di immagini. AD tra il 1965 e il 1973 pubblicò una

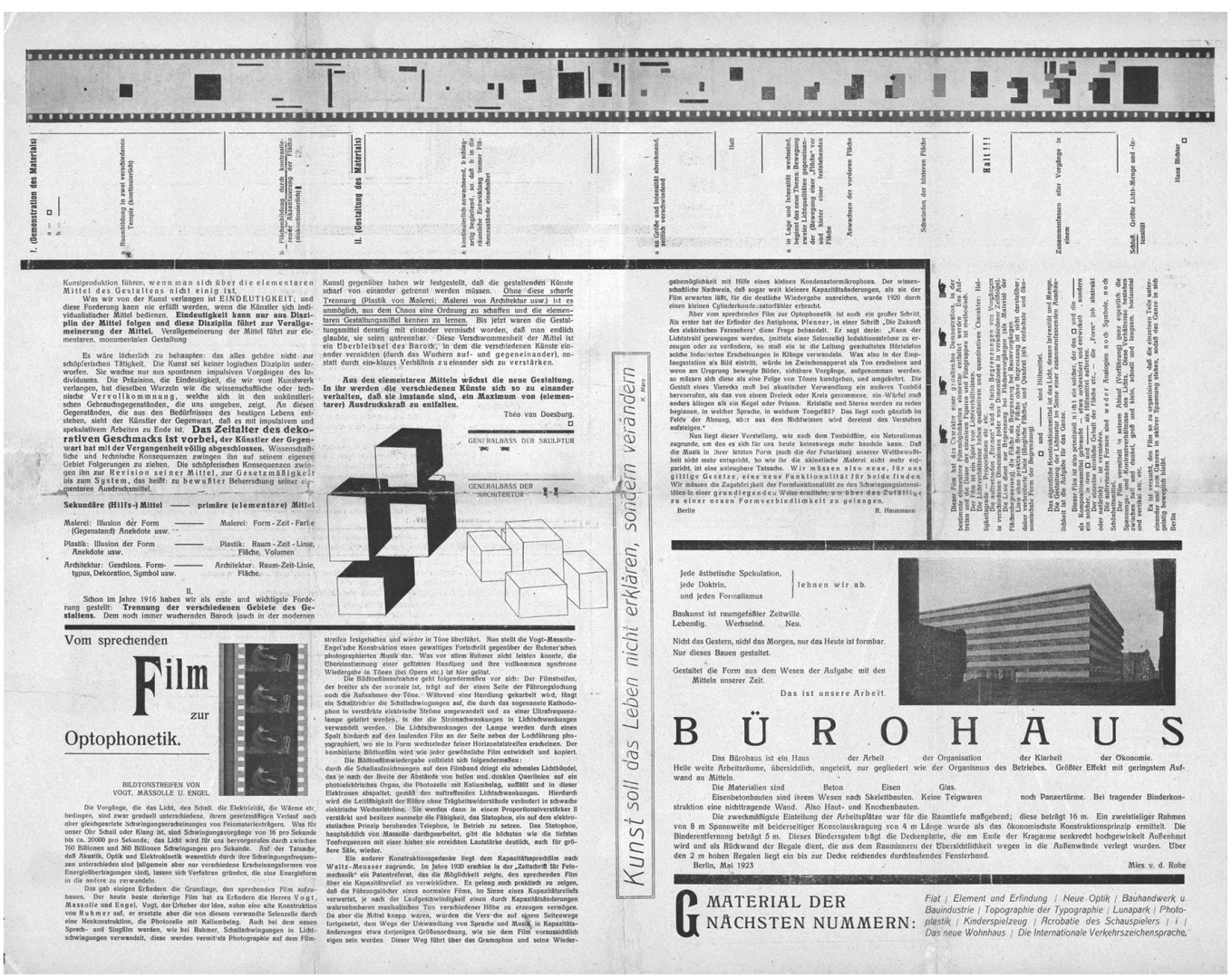




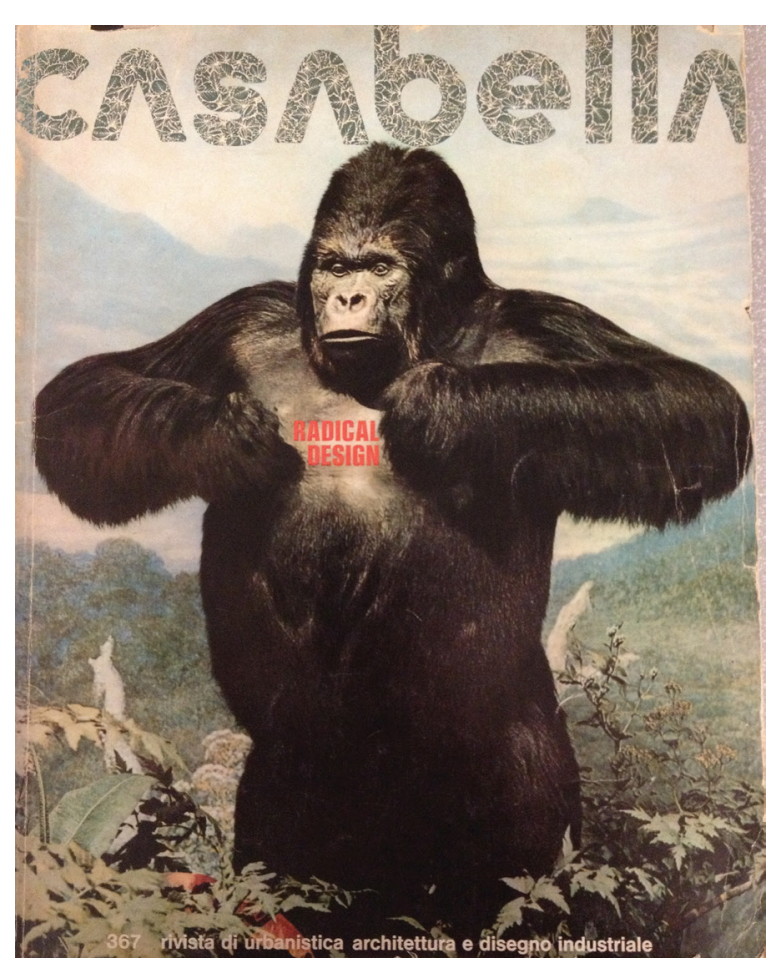

sezione della rivista, chiamata Cosmorama, che offriva un collage di immagini che ricostruivano una visione dell'architettura mondiale attraverso frammenti di fotografie tagliate da altre riviste e composte insieme per creare una narrazione con nuovi significati [Colomina 2010 ]. È proprio il collage la tecnica più caratteristica e innovativa utilizzata nell'ambito di queste sperimentazioni, sia per la rappresentazione dei progetti che per l'impaginazione delle riviste. Venivano realizzati fotomontaggi componendo frammenti di immagini fotografiche e disegni, in una sintesi visiva, corredata di segni e note a mano, che si poneva intrinsecamente come una narrazione. La tecnica del fotomontaggio, il cui utilizzo era stato già sperimentato dalle avanguardie artistiche nei primi decenni del Novecento, è parte inscindibile della progettazione per architetti come Hollein, Isozaki e il gruppo Archigram. Dal punto di vista tecnico, la disponibilità della stampa in offset che consentiva la riproducibilità su qualsiasi tipo di carta e formato, diede ulteriore impulso alla diffusione della tecnica del montaggio fotografico e del collage, ed alla nascita di numerose piccole riviste autoprodotte. L'assemblaggio di diversi contenuti deve però essere considerata un'operazione intellettuale ancor prima che fisica sul supporto della pagina, una sovrapposizione di idee, immagini, documenti, concetti derivati da altre discipline, selezionati, reinterpretati, trasferiti su un nuovo supporto e ricombinati per dare luogo a nuovi significati. Questa interpretazione è evidente fin dal titolo nella rivista Clip-Kit: Studies in environmental design, fondata nel 1966 da due studenti della Architectural Association, laddove la parola Kit indica gli strumenti, ovvero idee, immagini, documenti, concetti, e la parola Clip mostra il modo in cui questi prodotti sono tenuti insieme, dal punto di vista intellettuale o fisico. Nel caso della rivista, la necessità pratica di tenere insieme i fogli era risolta da un sistema di rilegatura in plastica, colorato, economico ed efficiente. I lettori erano invitati a staccare le pagine, rimuoverle, sostituirle o e comporle in un ordine differente, per cui la narrazione era immaginata come interattiva e partecipata [Buckley 2019].

Archigram Magazine, pubblicata a Londra dall'omonimo gruppo in 10 numeri a partire dal $196 \mid$, si avvicina maggiormente alle modalità narrative del fumetto, all'espressività della pop art, alle sperimentazioni tipografiche della 'poesia concreta' e della 'poesia visiva'. La tecnica rappresentativa è intrinsecamente legata ai significati da veicolare, attraverso una narrativa grafica che rappresenta un modo di mettere in scena la propria visione dell'architettura in 

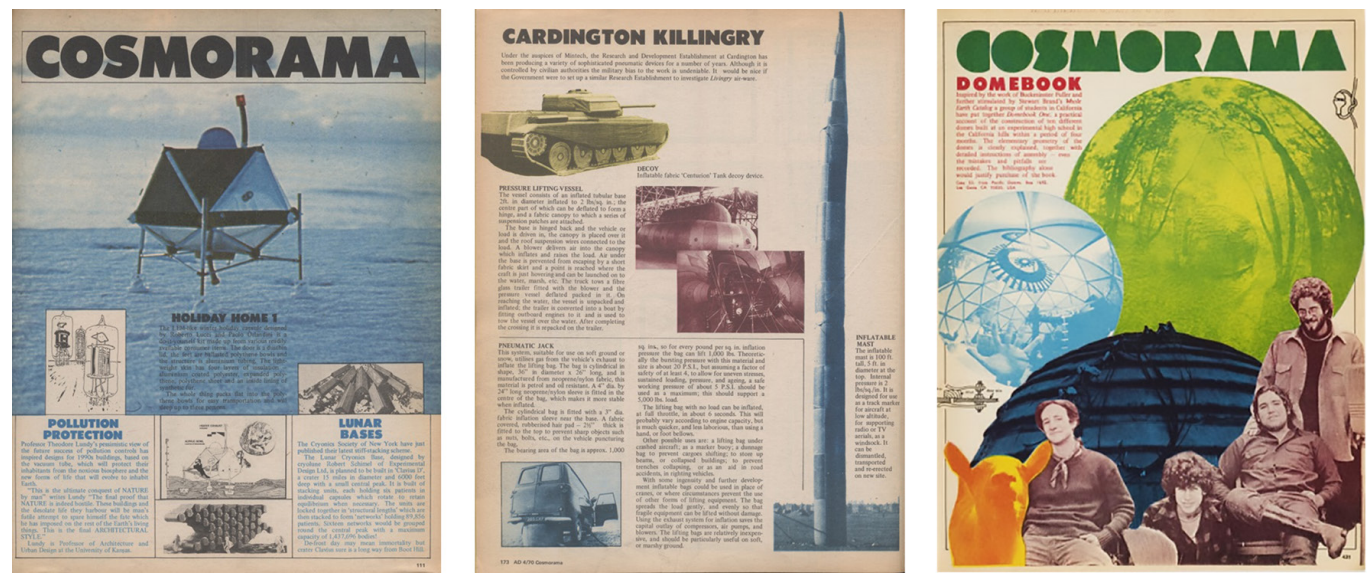

Fig. 7. Collage in coper tina e pagina interna d
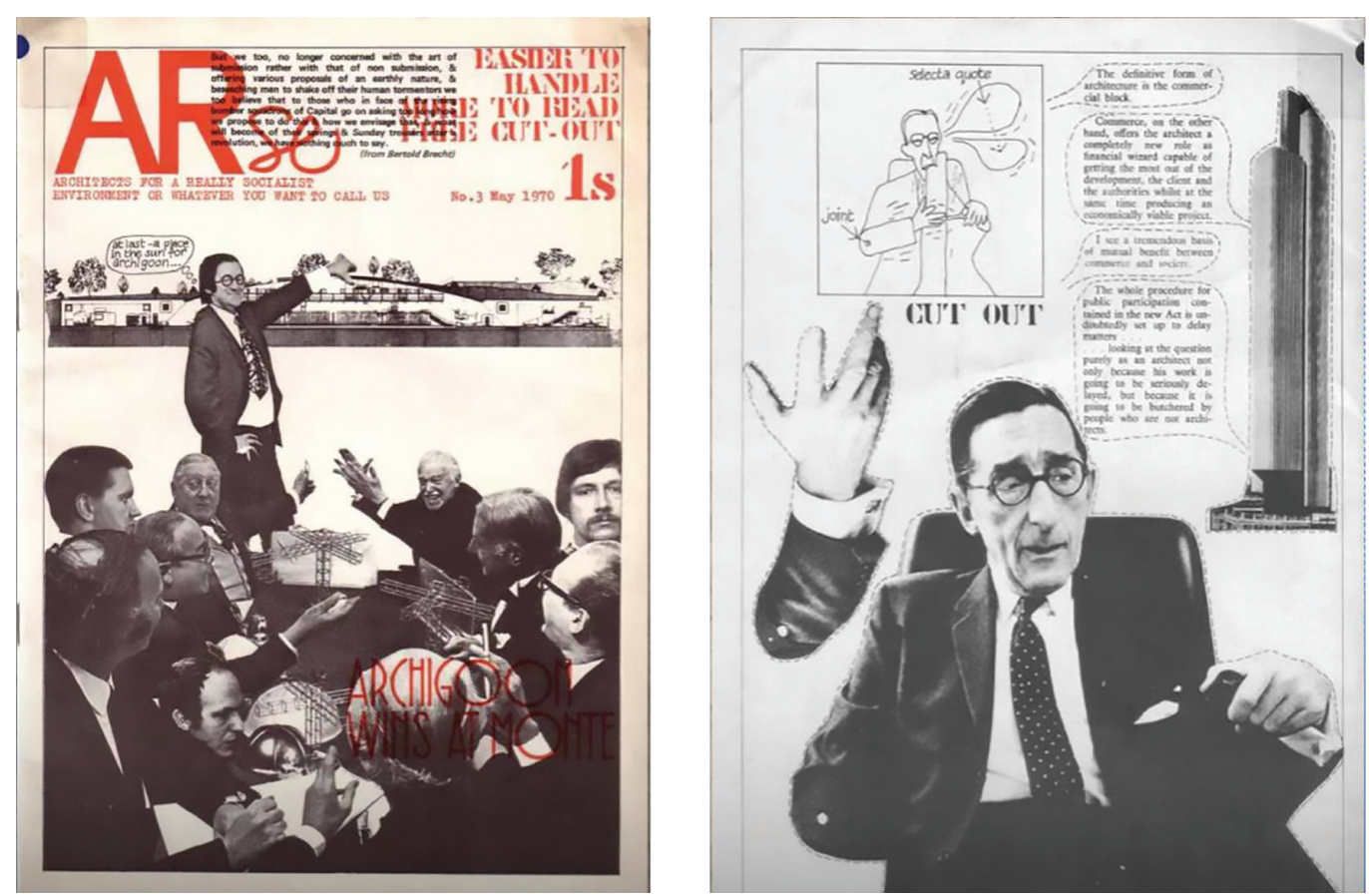
Fig. 8. Copertina con rilegatura in plastica di Clip-Kit: Studies in environmental design, I, 1966

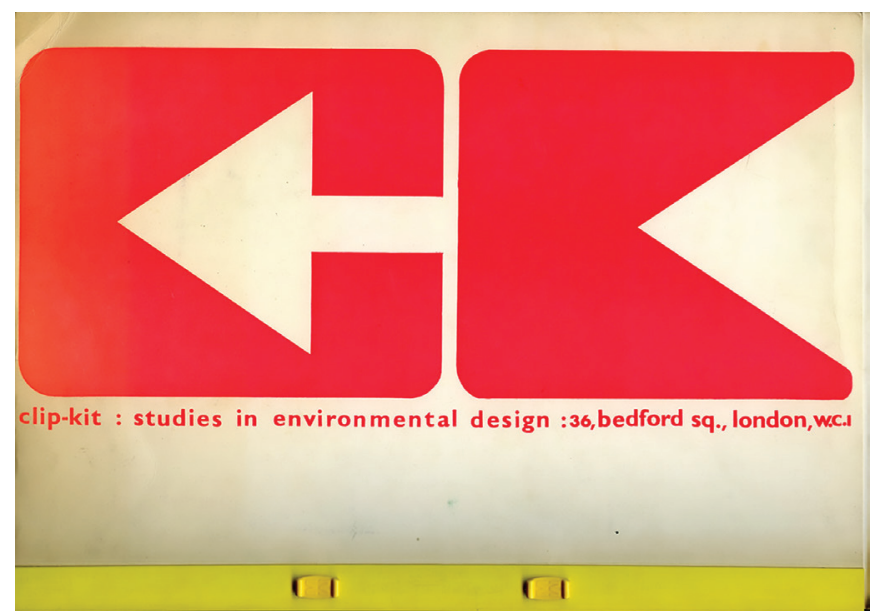

cui il processo conta più del risultato. In tal senso, è emblematico il numero 4 della rivista, (Amazing Archigram / Zoom), nel quale le prime pagine interne sono realizzate con le tipiche strisce dei fumetti di fantascienza, mentre il centro della rivista si apre con un pop up che mostra uno scenario urbano con l'invito "Pop up into a new world" [Steiner 2009].

Bau Magazine, pubblicato a Vienna dal 1965 al 1970, utilizzò un linguaggio che mescolava la pop art, la cultura architettonica, le suggestioni della conquista dello spazio, in accordo con il manifesto teorizzato da Hollein: "Everything is Architecture". A proposito di Bau, come delle altre riviste citate, è da notare come raramente l'architettura o gli architetti siano presentati in copertina, ulteriore elemento di distinzione dalle tradizionali riviste.

In conclusione, le riviste indipendenti di architettura (di cui qui per ragioni di spazio sono stati riportati solo pochi esempi ritenuti emblematici) forniscono il quadro di un'epoca in cui il dibattito uscì dalle rigide pagine delle riviste scientifiche per dar voce a nuove idee attraverso nuovi linguaggi espressivi, che in qualche modo si possono considerare precursori delle modalità di rappresentazione multimediale ed interattiva e dello storytelling come forma di narrazione partecipata, che hanno caratterizzato la comunicazione di architettura nell'era digitale.
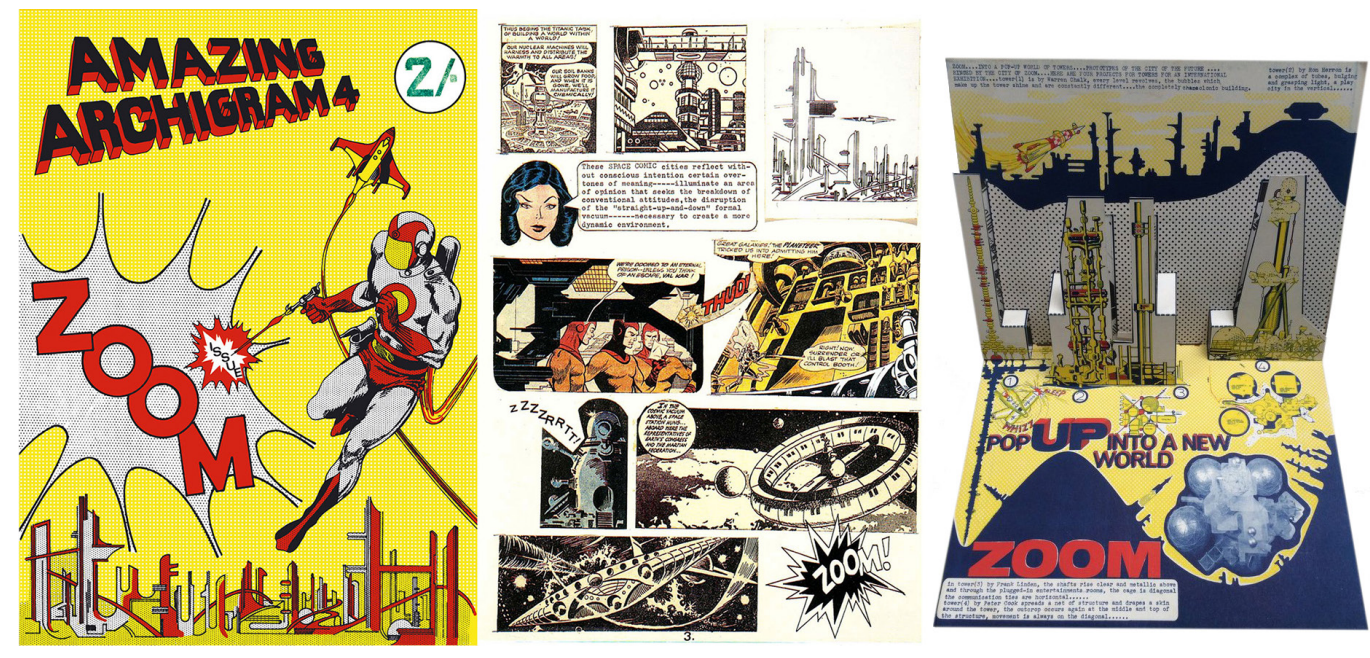

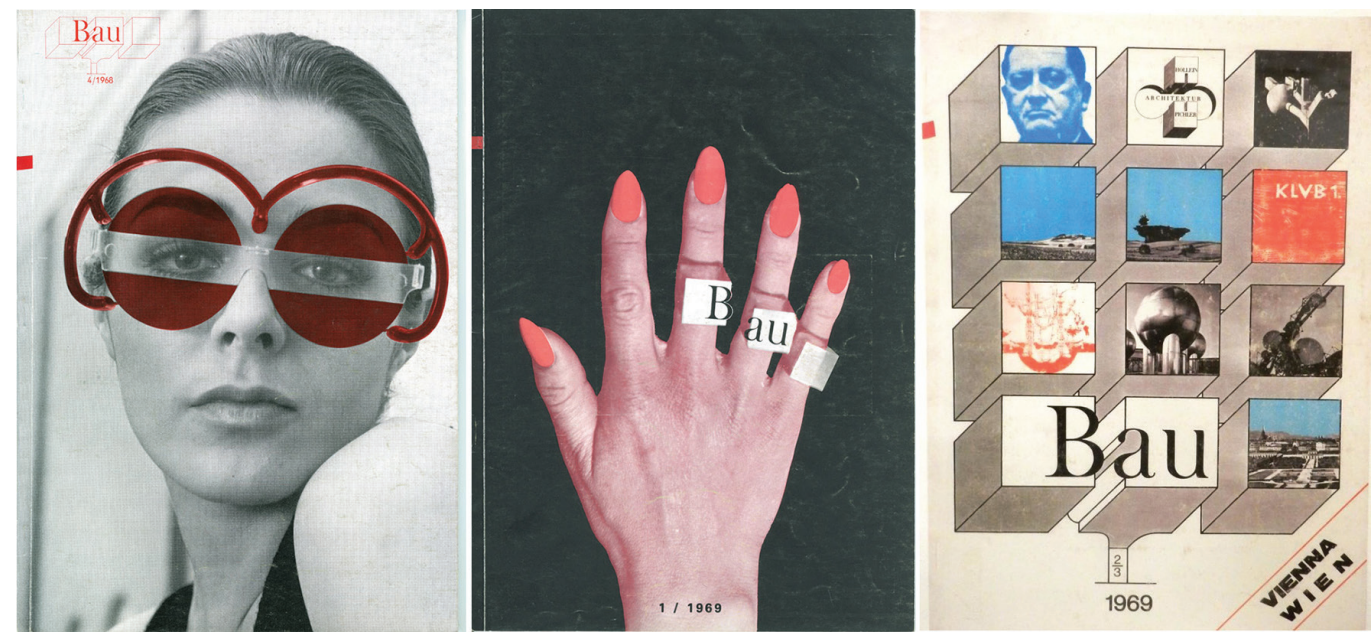

\section{Riferimenti bibliografici}

Buckley Craig (2019). Graphic Assembly: Montage, Media, and Experimental Architecture in the 1960s. USA: University of Minnesota press.

Bukminister Fuller Richard, Jérôme Agel, Quentin Fiore (1970). I seem to be a verb. New York: Bantam Books.

Celant Germano (1972). Radical Architecture. In Italy: The New Domestic Landscape. Exhibition catalogue, pp. 380-387. New York: Museum of Modern Art.

Colomina Beatriz (ed.) (2010). Clip, Stamp, Fold: The Radical Architecture of Little Magazines, 196X to 197X. USA: ACTAR Publishers.

Falcinelli Riccardo (20।4). Critica portatile al visual design. Da Gutemberg ai social network. Torino: Einaudi.

Grazioli Elio (200 I). Arte e pubblicità. Milano: Mondadori.

Hulten Pontus (a cura di). (1986). Futurismo e futurismi. Milano: Bompiani.

McLuhan Marshall, Fiore Quentin (1967). The medium is the massage. Berkeley, Ca: Gingko Press.

Mertins Detlef, Jennings Michael (ed.). (2010). G: An Avant-Garde Journal of Art, Architecture, Design, and Film, 1923-1926. Los Angeles: Getty Research Institute.

Munari Bruno (1993). Libri senza parole. In Pittarello Roberto. Per fare un libro. Milano: edizioni Sonda, pp. 7-9.

Peck Abe (1985). Uncovering the sixties: the life and times of underground press. New York: Citadel press.

Scott Brown Denise (1968). Little Magazines in Architecture and Urbanism. In Journal of the American Institute of Planners, Volume 34, Issue 4, pp. 223-233.

Steiner Hadas (2009). Archigram. The structure of circulation. New York: Routledge.

Wingler Hans Maria (1987). II Bauhaus. Weimar Dessau Berlino 1919-1933. Milano: Feltrinelli.

Autore

Manuela Piscitelli, Università degli Studi della Campania “LuigiVanvitelli”, manuela.piscitell@unicampania.it

Per citare questo capitolo: Piscitelli Manuela (2020). L'impaginato come forma narrativa: Le riviste sperimentali di architettura negli anni Sessanta/ The layout as a narrative form. Experimental architecture magazines in the Sixties. In Arena A., Arena M., Brandolino R.G., Colistra D., Ginex G. Mediati D., Nucifora S., Raffa P. (a cura di). Connettere. Un disegno per annodare e tessere. Atti del $42^{\circ}$ Convegno Internazionale dei Docenti delle Discipline della Rappresentazione/Connecting. Drawing for weaving relationships. Proceedings of the 42th International Conference of Representation Disciplines Teachers. Milano: FrancoAngeli, pp. 3700-3717. 


\section{The Layout as a Narrative Form. Experimental Architecture Magazines in the Sixties}

Manuela Piscitelli

\section{Abstract}

The paper proposes a study about the independent publications of the Sixties and early Seventies with reference to the architecture ones, analysing their visual characteristics. In that period, in fact, innovative research and experimentations of graphic narrative were carried out, in which the page layout assumed a fundamental importance in the communication of the contents. The overlapping of visual elements with the collage technique, the integration of texts and images, the use of characters, became functional to the communicative intent, establishing a close relationship between architectural theory and its representation and communication to a narrow audience interested in the debate on the renewal of architectural language.

Keywords

layout, experimental magazines, graphic narrative, collage.

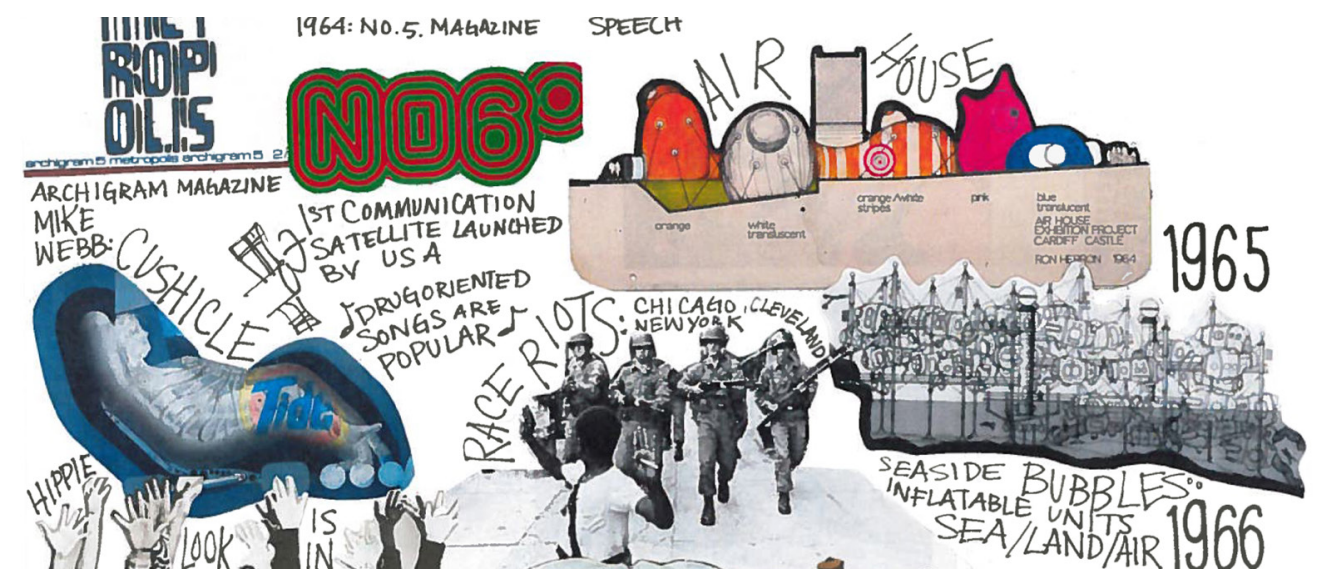


The printed page intended as a visual device has a narrative function which, particularly clearly in the illustrated page, defines a communication code. Its timing, unlike the cinematographic narration in which it is set at the time of montage, depends on the user, but it is guided by the designer who suggests visual paths, pauses, spaces where the narration takes place. This kind of graphic research has been carried out since the 1920s, when the artistic avant-garde experimentations, the art nouveau graphic art that unified figure and images with sinuous shapes and rich decorative elements [Grazioli 200 I], the breaking of the typographic cage operated by the Futurists with the words in freedom [Hulten 1986], the Bauhaus innovations on typefaces and the orientation of texts in the composition of the page [Wingler 1987], were all elements that converged in the typographic layout of illustrated books and magazines.

The first magazines to start these experimentations, where the sequence and the visual order of the contents presentation were intended as a narrative form, came from the fashion industry, which already in the first post-war period availed of the collaboration of artists, illustrators and then photographers, creating layouts where the images followed one another giving life to narrations, defining scenarios and settings that could arouse the desire to buy a dress to become part of the proposed imaginary.
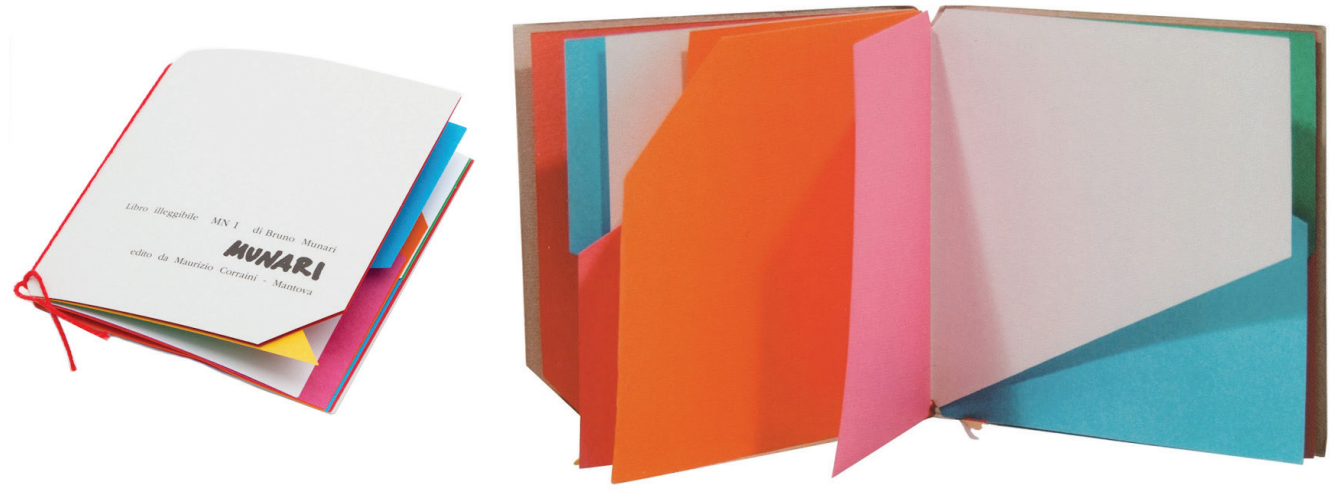

In the second post-war period, on an even more advanced front in the field of graphic narrative, there were experiments such as the "llegible books" created by Bruno Munari starting from 1949. Using papers of different types and grain, cut, perforated or torn in various ways and finally bonded to form a book, Munari conceived a storyline that does not use words but follows a purely visual line. Renouncing to be a support for the text, the paper communicates a message through its layout, the colour, the cuts and their alternation, a narration to follow using the senses [Munari 1993]. In contrast to the object book, which focused on the physical aspect of the unique piece displayed as a work of art, the illegible book is interesting from the point of view of representation as it focuses on the narrative potential. "The page, as a spatial unit, acquires in relation to the other pages a temporal dimension, becoming a rhythmic element. It does not impose an obligatory path, the book changes as the reader changes, demonstrating that it is superfluous to arrive at the loose pages of the avant-garde. This leads to an apparent paradox: turning the pages is a narrative experience but not a literary one" [Falcinelli 20 I4, p. 24I].

In the Sixties, illustrated magazines were used as a support for the most innovative experimentation from the point of view of typographic composition, exploiting all the narrative potential of the printed page in various fields including architecture, and in particular through niche publications often self-produced in the schools of architecture. The magazine as a visual device has its own identity, made up of a graphic style, a layout, a page architecture, a use of typefaces and cage that make it unique and recognizable by readers. This is a first level 
of communication, which could be defined as intrinsic, and is deeply linked to the public to which the magazine is addressed, to the technical innovations in the typographic field, to the trends of the time in art and graphics. The second level of communication is the content that the magazine selects and chooses to convey. Most of the studies published about magazines deal with the second level of communication, related to the contents, while the intrinsic communication, the staging of the contents, generally not taken into consideration, can be a point of reflection of great interest for the field of representation. Also in the field of architecture, the independent magazines known under the definition of 'small magazines' for their non-commercial role and the production in a few copies with limited circulation, have been studied with regard to the innovativeness of the contents conveyed rather than the equally innovative way in which these contents have been displayed through graphic narrative methods completely different from the classic representations of the projects in the publishing of that field. The definition of small magazines is not strictly applied to magazines, but to all the independent publishing activity that fed the debate on the renewal of architecture in that period, providing indications about new trends [Scott Brown 1968]. One of the most significant figures who worked in the editorial graphics of the time is certainly Quentin Fiore. His presence on the cover alongside the author, with equal importance, in revolutionary publications such as The medium is the massage (1967) with Marshall McLuhan and I seem to be a verb by Richard Bukminister Fuller (1970) show how the graphic mode of presentation had equal importance in the transmission as the content to be conveyed. Texts and visual codes merge in a synthesis where the communication, in addition to the verbal component, is entrusted to the visual component consisting of the layout
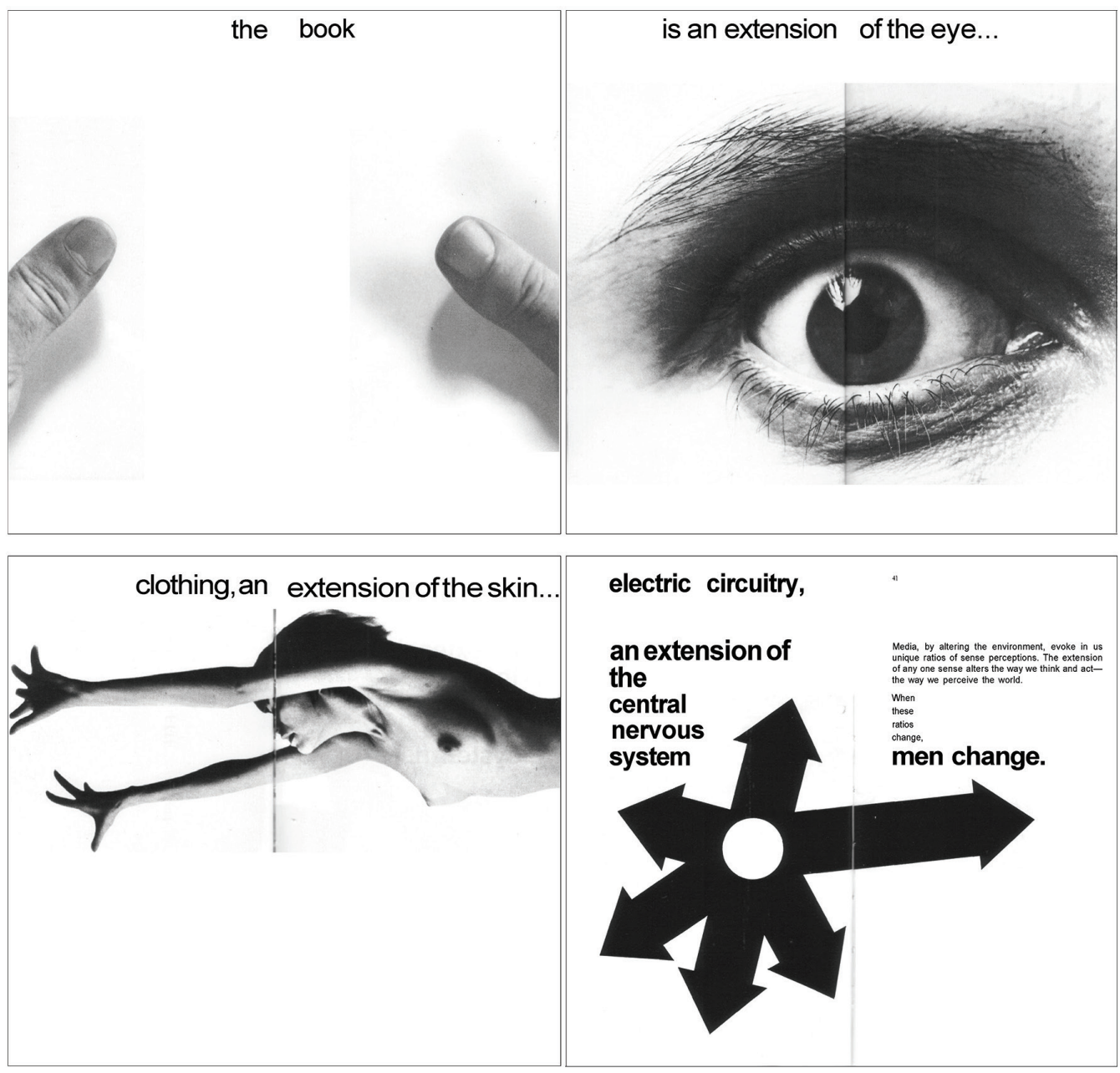
of texts and images on the double page, the onomatopoeic deformation of characters, the different visual weights, arrangement and orientation of texts, the alternation of pages with white background and pages with black background.

Fuller's text, I seem to be a verb, which deals with the society of the future and sustainable design, presents a collage of images of objects from the globalized society, provocatively juxtaposed through a visual montage made of continuous cross-references that provide the sense of narration. The composition is made on the double page divided into horizontal bands, the upper one in black and white, the lower one in green and upside down, so that two different stories share the same visual space and the book can be read straight or upside down with different contents and meanings.

Between the Sixties and Seventies, independent architecture magazines were an open field for debate, laboratories of ideas and experimentation expressed with new and avant-garde languages. As a tool for spreading new ideas, they linked to the magazines of the 1920s, from whose pages the masters of architecture had disseminated their ideas, such as L'Esprit Nouveau by le Corbusier (1920-1925) and G: Material zur elementaren Gestaltung by Mies van der Rohe (1923-1926), from which they resumed their role as a channel of debate for the avant-garde. While L'Esprit Nouveau had a traditional typographic approach, in $G$ the graphic research was part of the communicative project, as demonstrated by the constructivist typographic layout created by El Lissitzky [Mertins 20 I0].

From the point of view of the graphic language, in the Sixties many magazines were composed by the curators themselves, through the overlapping of different visual elements with the technique of collage: fragments of images, photographs, drawings, handwritten or printed texts in combinations of different types of characters, all composed on the page in dynamic layouts that guided the perception in a meaningful narrative. The support for these compositions could also be variable, papers of various weights and colours, simple sheets

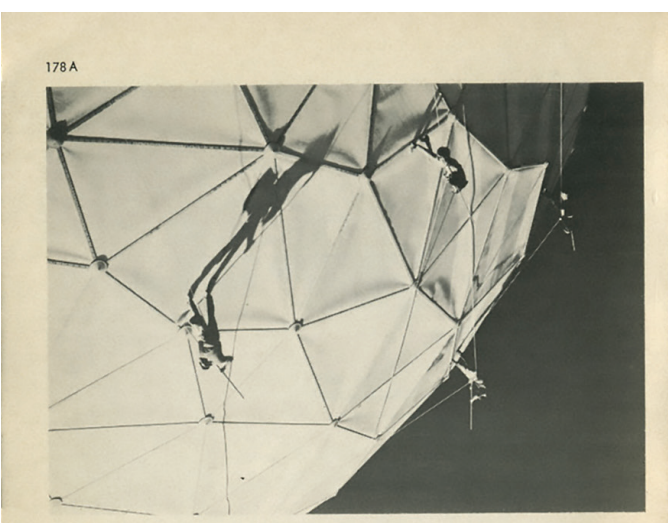

E OF UNBIASED INTEGR WI ISOW $\exists G \quad$ NVW VNIHO

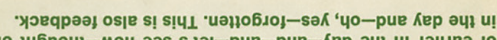

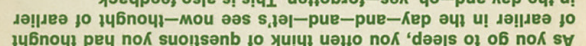

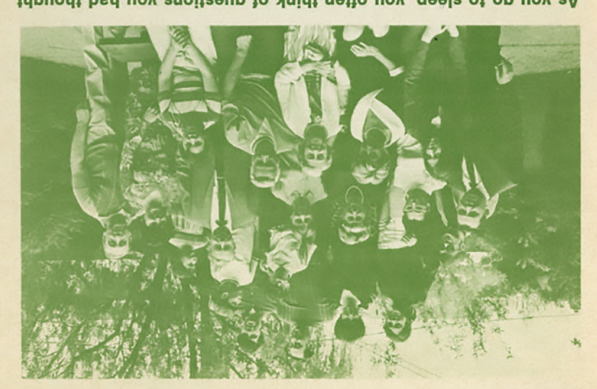

8 841

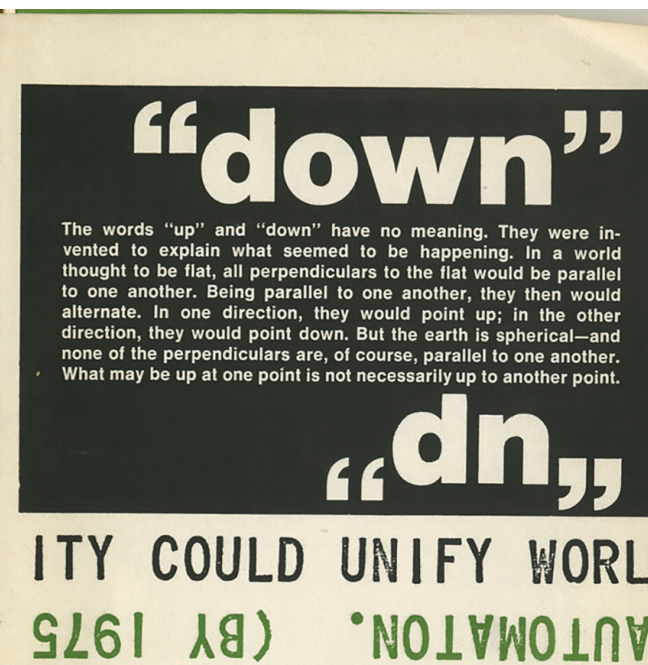

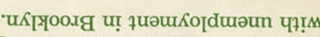

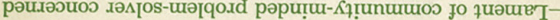

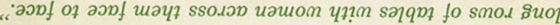

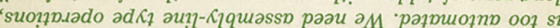

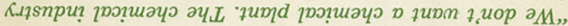

.

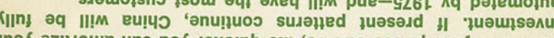

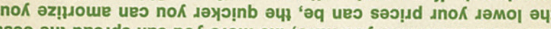

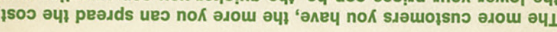

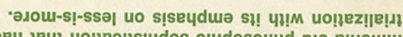

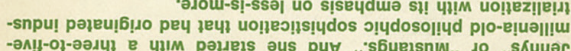

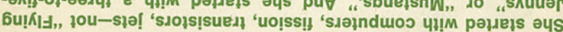

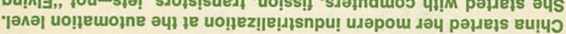


bound in various ways or loose, large folded formats [Peck 1985]. The way in which the contents were presented was functional to the communicative intent, in a close relationship between architectural theory (the most interesting and innovative projects were often destined to remain on paper) and its representation and communication to a niche audience interested in the debate. Publications of this type can be found in different geographical areas, sharing the same expressive means derived from the graphic language of the artistic avant-garde, the desire to break away from the conventions of the past, the experimentation of new modes of expression that could convey new contents, differing profoundly from traditional architecture magazines, characterized by the presentation of technical drawings illustrating the projects and didactic texts. These publications were also representatives for what Germano Celant called radical Italian architecture [Celant 1972].

The visual codes of the period were strongly influenced by spatial programs, which led to a reflection on architecture and environment in spaces to be colonized or uninhabitable environments. These reflections are evident in magazines such as Clip-Kit, Archigram, and Bau, as well as in the works published by the Superstudio group on the pages of Casabella magazine. About structured magazines such as Casabella or Architectural Design, it has been noticed how in this same period they had a temporary detachment from the more commercial logics that characterized them, to become the voice of groups and debates of the time. The new editorial logic can also be seen in the layout of the pages and in the graphic design of the covers, which changed from the traditional approach to become a space for experimentations appropriate to the contents they were conveying at the time. Between 1970 and 1975, under the direction of Alessandro Mendini, Casabella gave ample space to research into radical architecture and at the same time renewed the graphics. The covers of those years are provocative, they don't show projects as typically happened up to that moment and will continue afterwards, they use image collages. Between 1965 and 1973 AD

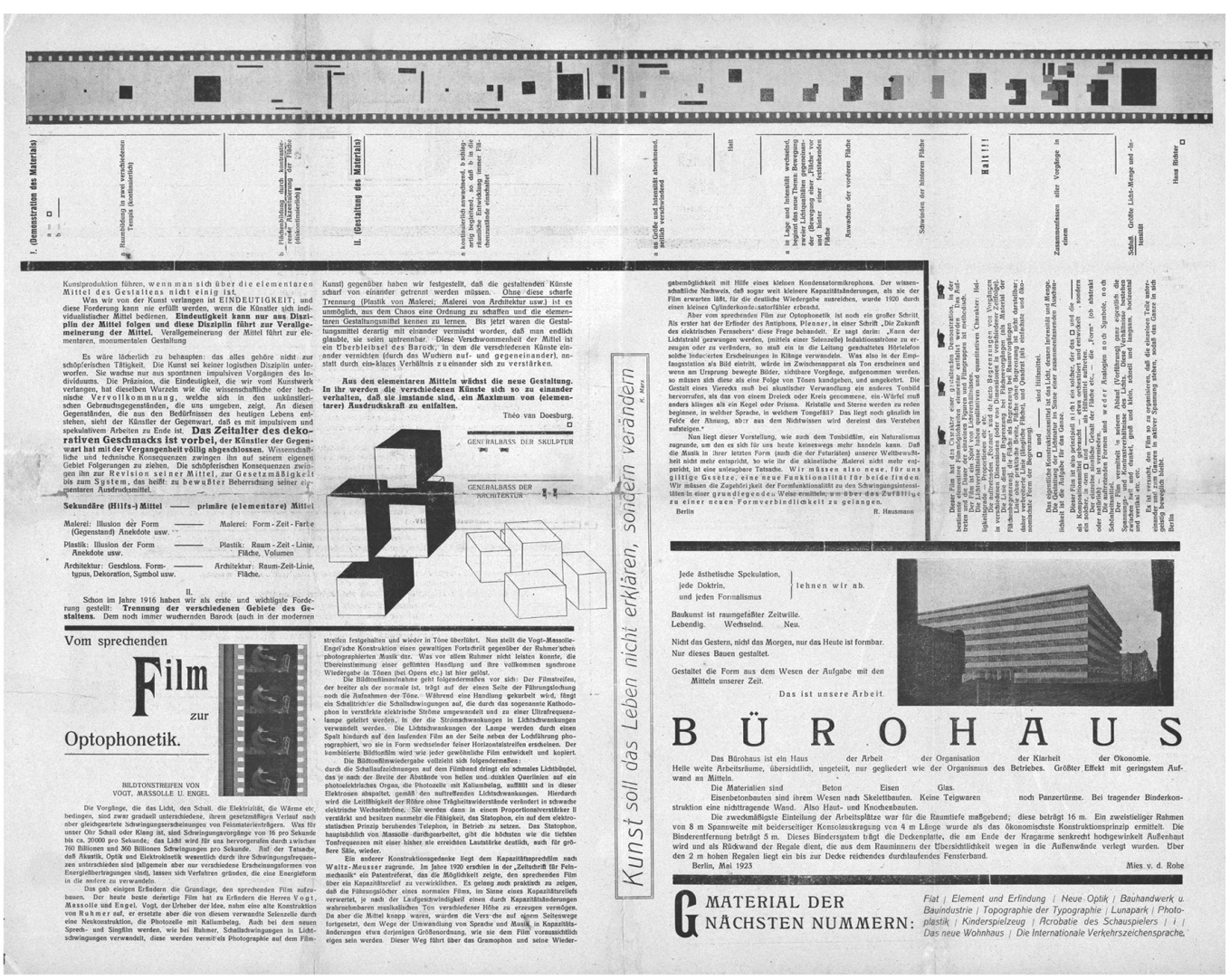




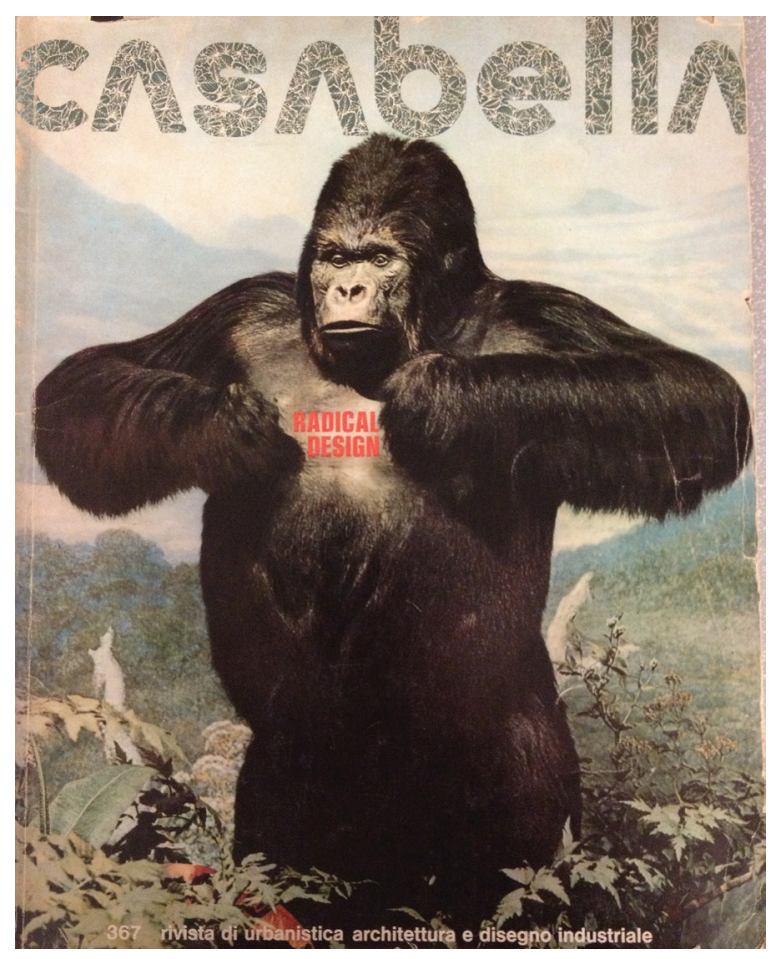

published a section of the magazine, called Cosmorama, which offered a collage of images that reconstructed a vision of world architecture through fragments of photographs cut from other magazines and composed together to create a narration with new meanings [Colomina 2010].

Collage is the most characteristic and innovative technique used in these experiments, both for the representation of the projects and for the layout of the magazines. Photomontages were made by composing fragments of photographic images and drawings in a visual synthesis, accompanied by signs and hand notes, which was intrinsically a narration. The technique of photomontage, whose use had already been experimented by the artistic avant-garde in the early decades of the Twentieth Century, is an inseparable part of design for architects such as Hollein, Isozaki and the Archigram group. From a technical point of view, the availability of offset printing that allowed reproducibility on any type of paper and format, gave further impetus to the spread of the technique of photographic montage and collage, and the birth of numerous small self-produced magazines. The assembly of different contents, however, must be considered an intellectual operation even before a physical one on the page support, an overlapping of ideas, images, documents, concepts derived from other disciplines, selected, reinterpreted, transferred on a new support and recombined to give rise to new meanings. This interpretation is evident even from the title in the magazine Clip-Kit: Studies in environmental design, founded in 1966 by two students of the Architectural Association, where the word Kit indicates the tools: ideas, images, documents, concepts, and the word Clip shows how these products are held together, intellectually or physically. In the case of the magazine, the practical need to hold the sheets together was solved by a colourful, inexpensive and efficient plastic binding system. Readers were invited to tear the pages, remove them, replace them or compose them in a different order, so the narrative was imagined as interactive and participatory [Buckley 2019].

Archigram Magazine, published in London by the homonymous group in 10 issues since $196 \mid$, is closer to the narrative modalities of comics, to the expressiveness of pop art, to the typographic experimentations of 'concrete poetry' and 'visual poetry'. The representative technique is intrinsically linked to the meanings to be conveyed, through a graphic narrative that represents a way of staging their own vision of architecture in which the process coun- 
Fig. 6. Pages from the section Cosmorama of $A D$ magazine, 1970.
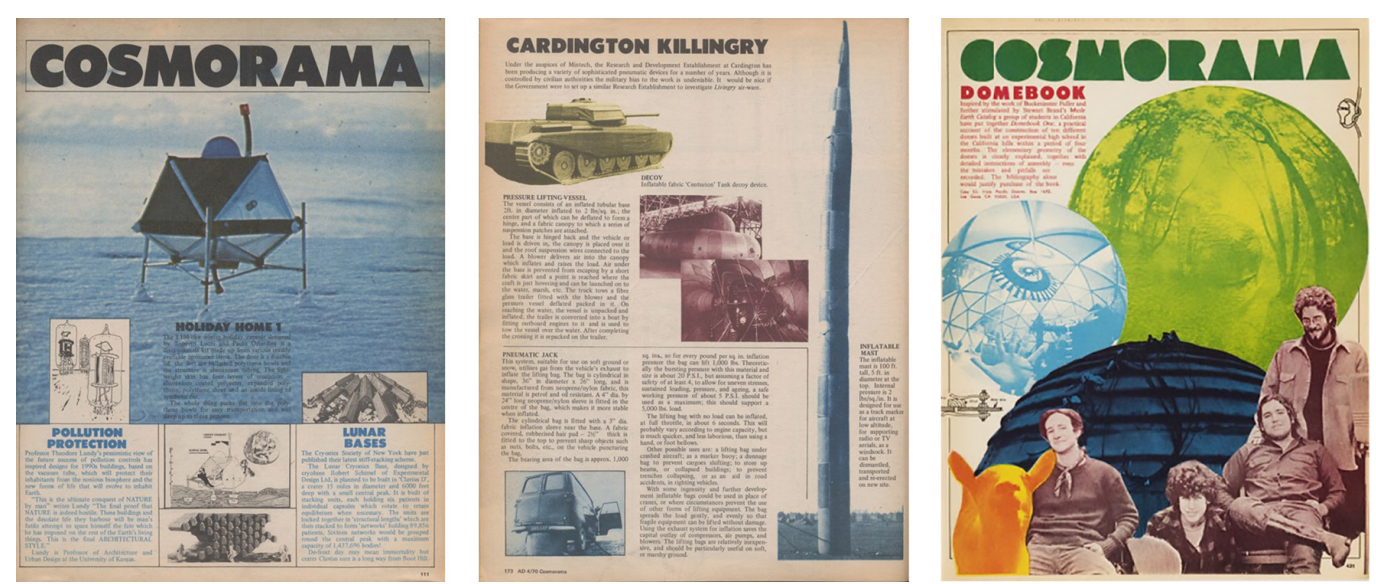
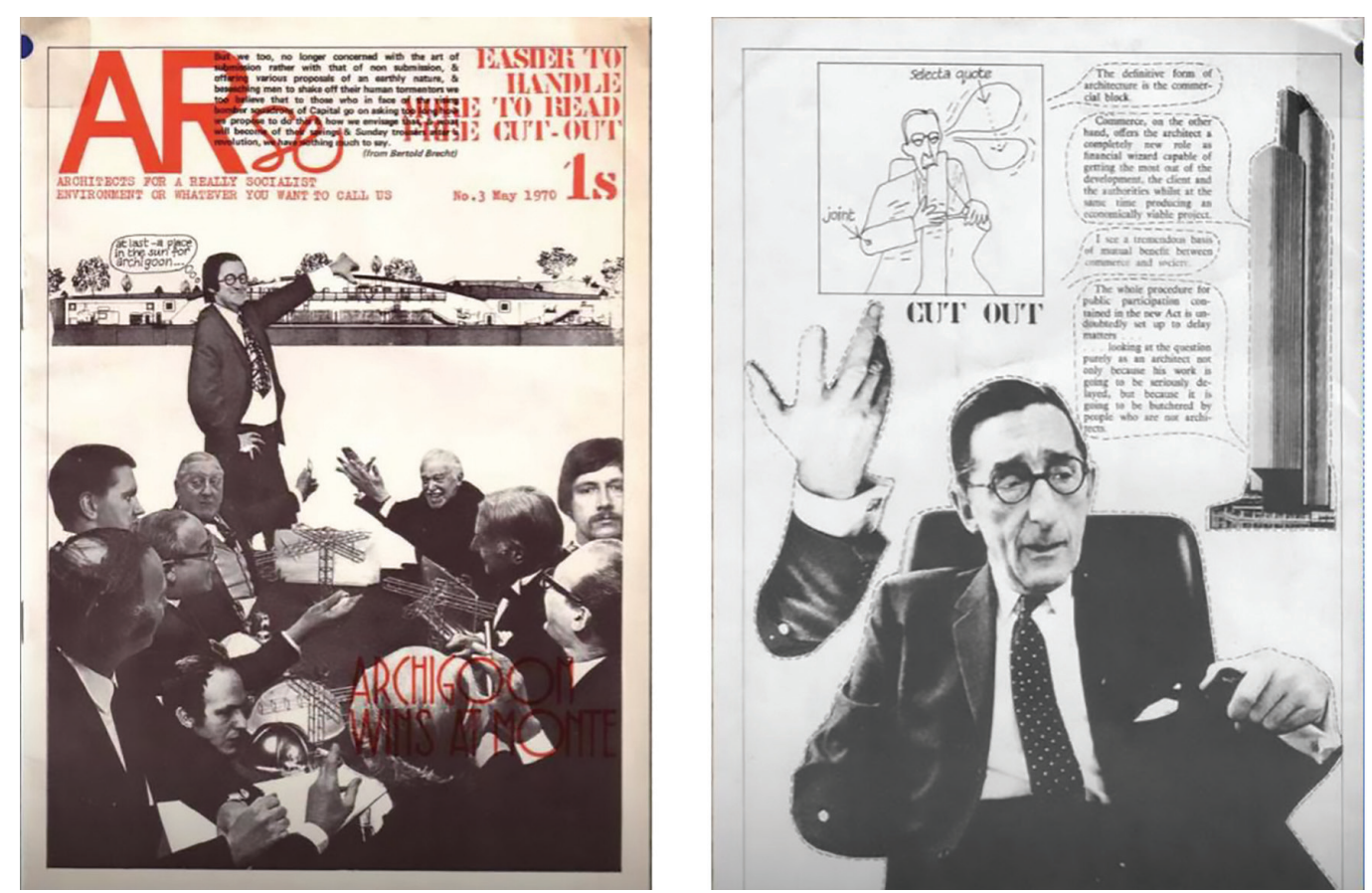
Fig. 8. Cover with plastic binding of Clip-Kit: Studies in environmental design, n. I. 1966.

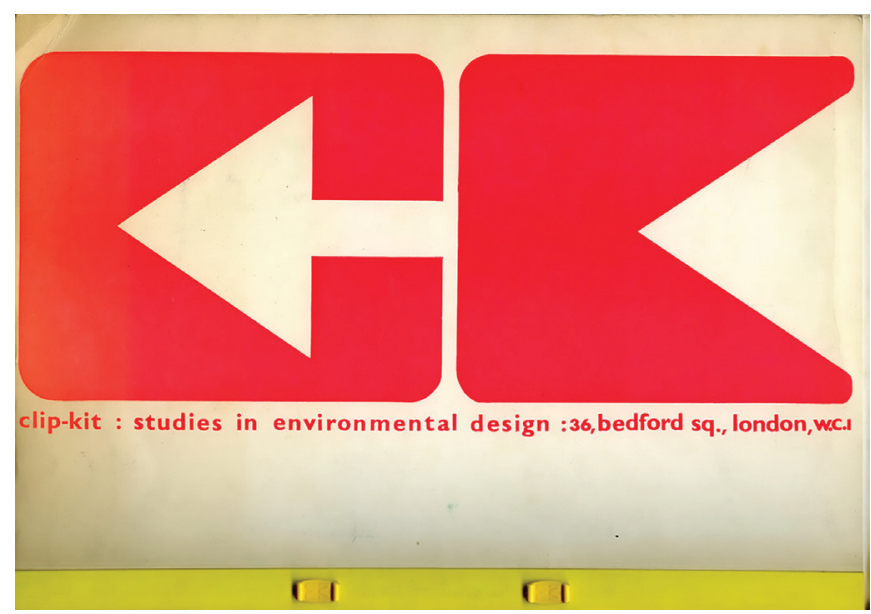

ts more than the result. In this sense, the number 4 of the magazine, (Amazing Archigram / Zoom) is emblematic, whose first internal pages are made with the typical strips of science fiction comics, while the centre of the magazine opens with a pop up that shows an urban scenario with the invitation "Pop up into a new world" [Steiner 2009].

Bau Magazine, published in Vienna from 1965 to 1970, used a language that mixed pop art, architectural culture and the suggestions of the conquest of space, in accordance with the manifesto theorized by Hollein: "Everything is Architecture". Regarding Bau, as with the other magazines mentioned, it should be noted that architecture or architects are rarely presented on the cover, another element of distinction from traditional magazines.

In conclusion, the independent magazines of architecture (of which only a few emblematic examples have been reported here for space reasons) provide the context of an era in which the architecture debate broke out of the rigid pages of scientific journals to give voice to new ideas through new expressive languages, which can somehow be considered precursors of multimedia and interactive representation and storytelling as a form of participatory narration, which have characterized the communication of architecture in the digital age.
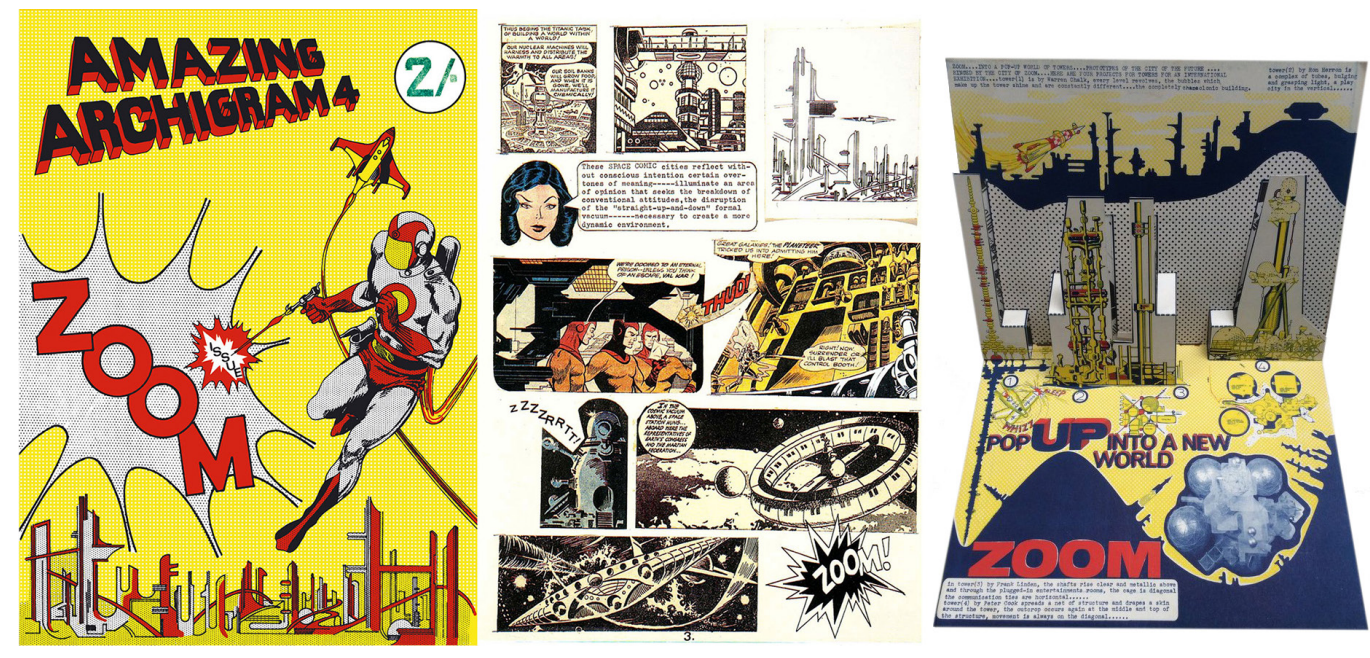

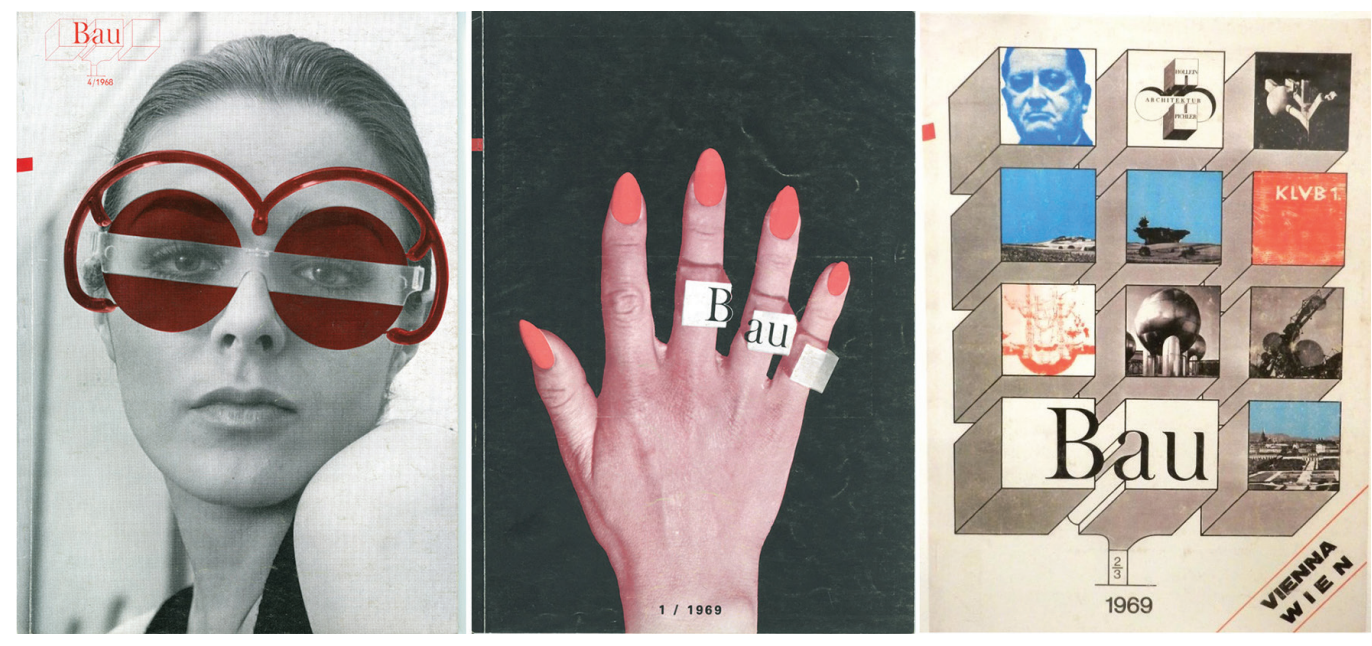

References

Buckley Craig (2019). Graphic Assembly: Montage, Media, and Experimental Architecture in the 1960s. USA: University of Minnesota press.

Bukminister Fuller Richard, Jérôme Agel, Quentin Fiore (1970). I seem to be a verb. New York: Bantam Books.

Celant Germano (1972). Radical Architecture. In Italy: The New Domestic Landscape. Exhibition catalogue, pp. 380-387. New York: Museum of Modern Art.

Colomina Beatriz (ed.) (2010). Clip, Stamp, Fold: The Radical Architecture of Little Magazines, 196X to 197X. USA: ACTAR Publishers.

Falcinelli Riccardo (20।4). Critica portatile al visual design. Da Gutemberg ai social network. Torino: Einaudi.

Grazioli Elio (200I). Arte e pubblicità. Milano: Mondadori.

Hulten Pontus (a cura di). (1986). Futurismo e futurismi. Milano: Bompiani.

McLuhan Marshall, Fiore Quentin (1967). The medium is the massage. Berkeley, Ca: Gingko Press.

Mertins Detlef, Jennings Michael (ed.). (20 I0). G: An Avant-Garde Journal of Art, Architecture, Design, and Film, 1923-1926. Los Angeles: Getty Research Institute.

Munari Bruno (1993). Libri senza parole. In Pittarello Roberto. Per fare un libro. Milano: edizioni Sonda, pp. 7-9.

Peck Abe (1985). Uncovering the sixties: the life and times of underground press. New York: Citadel press.

Scott Brown Denise (1968). Little Magazines in Architecture and Urbanism. In Journal of the American Institute of Planners, Volume 34, Issue 4, pp. 223-233.

Steiner Hadas (2009). Archigram. The structure of circulation. New York: Routledge.

Wingler Hans Maria (1987). II Bauhaus. Weimar Dessau Berlino 1919-1933. Milano: Feltrinelli.

Author

Manuela Piscitelli, Università degli Studi della Campania “Luigi Vanvitelli”, manuela.piscitelli@unicampania.it

To cite this chapter: Piscitelli Manuela (2020). L'impaginato come forma narrativa: Le riviste sperimentali di architettura negli anni Sessanta/The layout as a narrative form. Experimental architecture magazines in the Sixties. In Arena A., Arena M., Brandolino R.G., Colistra D., Ginex G., Mediat D., Nucifora S., Raffa P. (a cura di). Connettere. Un disegno per annodare e tessere. Atti del $42^{\circ}$ Convegno Internazionale dei Docenti delle Discipline della Rappresentazione/Connecting. Drawing for weaving relationships. Proceedings of the 42th International Conference of Representation Disciplines Teachers. Milano: FrancoAngeli, pp. 3700-3717. 